\title{
Season, but not symbiont state, drives microbiome structure in the temperate coral Astrangia poculata
}

\author{
Koty H. Sharp ${ }^{*}$, Zoe A. Pratte ${ }^{2}$, Allison H. Kerwin ${ }^{3}$, Randi D. Rotjan ${ }^{4,5}$ and Frank J. Stewart ${ }^{2}$
}

\begin{abstract}
Background: Understanding the associations among corals, their photosynthetic zooxanthella symbionts (Symbiodinium), and coral-associated prokaryotic microbiomes is critical for predicting the fidelity and strength of coral symbioses in the face of growing environmental threats. Most coral-microbiome associations are beneficial, yet the mechanisms that determine the composition of the coral microbiome remain largely unknown. Here, we characterized microbiome diversity in the temperate, facultatively symbiotic coral Astrangia poculata at four seasonal time points near the northernmost limit of the species range. The facultative nature of this system allowed us to test seasonal influence and symbiotic state (Symbiodinium density in the coral) on microbiome community composition.

Results: Change in season had a strong effect on A. poculata microbiome composition. The seasonal shift was greatest upon the winter to spring transition, during which time A. poculata microbiome composition became more similar among host individuals. Within each of the four seasons, microbiome composition differed significantly from that of surrounding seawater but was surprisingly uniform between symbiotic and aposymbiotic corals, even in summer, when differences in Symbiodinium density between brown and white colonies are the highest, indicating that the observed seasonal shifts are not likely due to fluctuations in Symbiodinium density.

Conclusions: Our results suggest that symbiotic state may not be a primary driver of coral microbial community organization in A. poculata, which is a surprise given the long-held assumption that excess photosynthate is of importance to coral-associated microbes. Rather, other environmental or host factors, in this case, seasonal changes in host physiology associated with winter quiescence, may drive microbiome diversity. Additional studies of A. poculata and other facultatively symbiotic corals will provide important comparisons to studies of reef-building tropical corals and therefore help to identify basic principles of coral microbiome assembly, as well as functional relationships among holobiont members.
\end{abstract}

Keywords: Coral microbiome, temperate corals, Astrangia poculata

\section{Background}

Corals are the foundation of tropical reef ecosystems worldwide and are increasingly known to harbor prevalent and ecologically important microbial communities (reviewed in [1]). The now classic two-partner symbiosis between the coral host and intracellular photosynthetic symbiont (Symbiodinium) has been updated to include the microbiome, with corals now regarded as metaorganisms [2]: metazoan hosts with diverse bacterial, archaeal, fungal, protistan, and viral partners [3]. Much

\footnotetext{
*Correspondence: ksharp@rwu.edu

'Department of Biology, Marine Biology and Environmental Science, Roger

Williams University, 1 Old Ferry Road, Bristol, RI 02809, USA

Full list of author information is available at the end of the article
}

of the coral microbiome research over the past two decades has focused on prokaryotic communities and has consistently demonstrated that prokaryotes in tropical corals play a critical role in nutrient acquisition and waste processing $[4,5]$ and host resistance to pathogens $[6,7]$ and are therefore largely beneficial to corals and coral reefs $[3,8,9]$. Most corals appear to acquire their specific bacterial component from seawater during early life stages [10, 11], although intergenerational transmission may also occur $[12,13]$. Yet, coralassociated microbiomes are distinct from those in the surrounding seawater and sediment [14-17], and the mechanisms that regulate the composition of the coral microbiome remain largely unknown. These could 
include variation in the host's physiology (e.g., due to developmental stage), the activity and abundance of host-associated Symbiodinium, and the chemical and physical properties of the surrounding environment, with all of these potentially linked to both natural (seasonal) and anthropogenic changes in ocean conditions.

Research suggests that the native coral microbiome changes in the face of environmental stress $[1,7,8,18-21]$. Tropical coral reefs are threatened by a wide variety of stressors, including pollution, overfishing, ocean acidification, and ocean warming, with the latter capable of affecting corals at the global scale [22-24]. Notably, recent sustained warming events [25] have triggered massive coral bleaching across ocean basins. Bleaching, which involves loss of intracellular photosynthetic Symbiodinium, triggers rapid changes in physiological interactions in tissue, skeleton, and mucus layers, with observed taxonomic and genomic changes in the coral microbiome [19, 26, 27]. In tropical corals, sustained warming events and resultant loss of Symbiodinium (bleaching) have been shown to result in a decrease in defensive properties of coral mucus and bioactivity against known coral pathogens [7], potentially allowing for infection and disease $[9,28]$. However, the biochemical processes that drive these microbiome shifts are still not well understood, and it is unclear whether the shifts that follow bleaching are a response to the loss of Symbiodinium, to increased temperature, or to both. It is therefore crucial to assemble a model of microbe-microbe interactions within the coral meta-organism that can describe the relative roles of Symbiodinium versus environmental conditions, such as temperature, as drivers of prokaryotic diversity.

Studies of corals with naturally varying Symbiodinium levels, notably if spanning seasonal fluctuations in temperature, provide valuable opportunities to tease apart interactions among environmental conditions, Symbiodinium, and prokaryotic communities in corals. Because most tropical corals have an obligate relationship with Symbiodinium, it is impossible to distinguish stress due to symbiont loss from stress due to the environmental change that resulted in symbiont loss. The facultatively symbiotic temperate coral Astrangia poculata (the "Northern Star Coral"; Fig. 1) is an ideal alternative study system for exploring the interplay among members of the coral meta-organism without unnaturally disturbing the typically obligate symbiosis. A. poculata engages in facultative symbiosis with only one species of symbiont, Symbiodinium psygmophilum (ITS2 Type B2) [29, 30]. Sympatric A. poculata individuals can exhibit wide variation in S. psygmophilum density [31]. As a temperate species, $A$. poculata also experiences a wide range of temperatures throughout the year. In the species' northernmost range (southern New England), seawater temperature fluctuates over a range exceeding $20{ }^{\circ} \mathrm{C}$, with average temperatures from 4 to $29^{\circ} \mathrm{C}$ across seasons (NOAA Tides \& Currents, Newport, RI: site 8452660). As a consequence, A. poculata metabolic rates vary seasonally, with the coral entering into quiescence

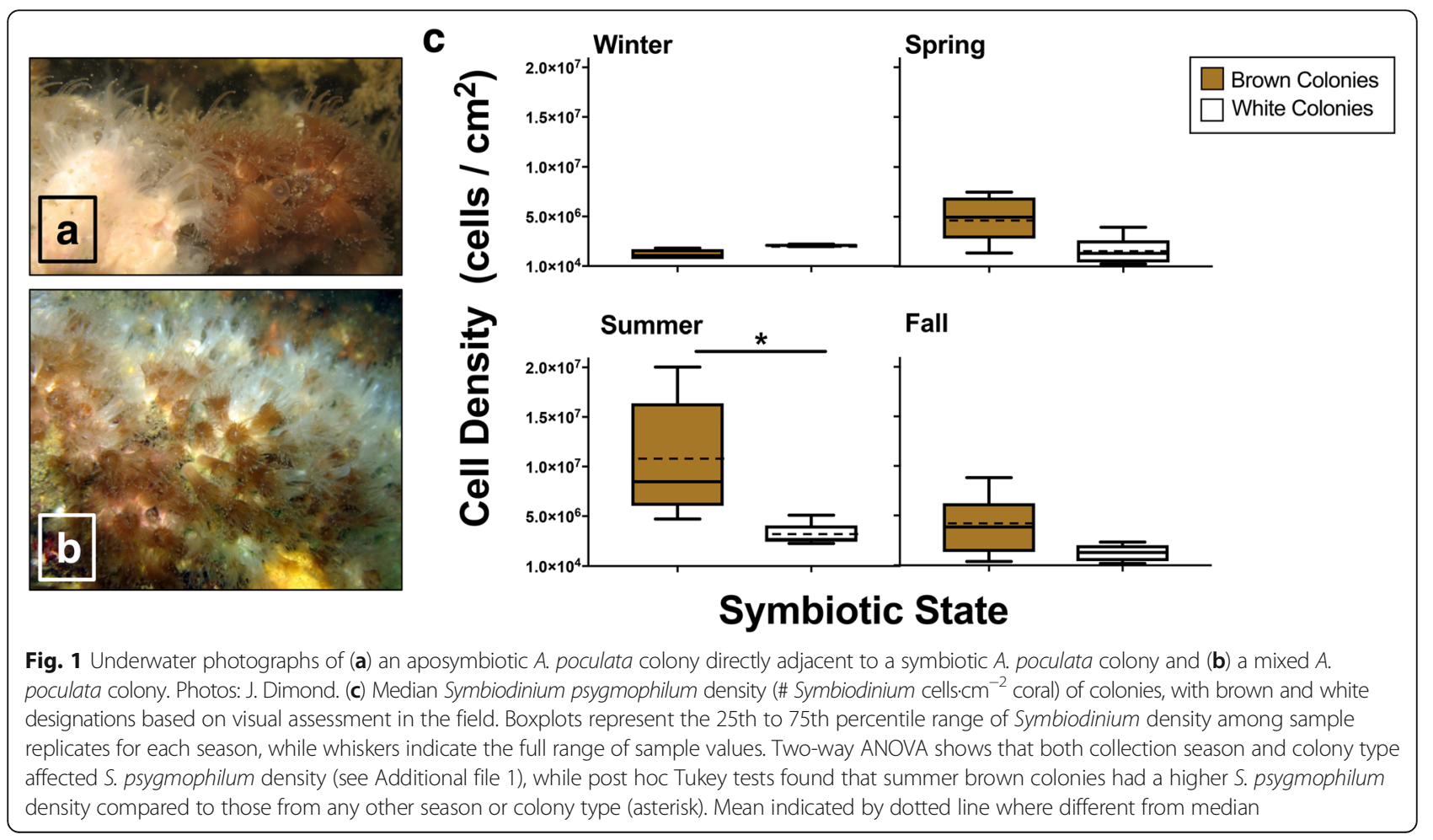


(dormancy) during winter months [30, 32, 33], with reduced symbiosis during this quiescent period [34]. Studies of $A$. poculata in its natural environment across seasons therefore allow testing of the influence of symbiosis and seasonality on other aspects of the meta-organism.

Here, we present the first description of prokaryotic diversity in the coral A. poculata, sampled over seasons from a location in Narragansett Bay, Rhode Island, near the northernmost limit of the species range. In this study, we refer to the associated prokaryotic community as the "microbiome." The sampled A. poculata individuals vary in symbiotic state, or density of S. psygmophilum cells in coral tissue, as (a) symbiotic or "brown"; (b) aposymbiotic or "white"; or (c) "mixed" (colonies are mottled and have localized regions of relatively high cell density). Symbiotic states have previously been assigned according to color and approximated chlorophyll concentration [32, 35, 36] and cell density of Symbiodinium in summer months [37], with brown colony Symbiodinium densities exceeding $10^{6}$ cells $\mathrm{cm}^{-2}$ coral tissue, and white colony Symbiodinium densities ranging from $10^{4}$ to $10^{6}$ cells $\mathrm{cm}^{-2}$ [37].

By sampling both across seasons and across colonies varying in symbiotic state, our objective is to determine whether the taxonomic structure of the microbiome in A. poculata is linked to symbiotic state or to other factors that fluctuate seasonally. We hypothesized that (1) microbiome composition would vary significantly across seasons and (2) within seasons, especially within summer, symbiotic state would be a significant driver of microbiome composition.

\section{Methods}

\section{Coral and seawater specimen collection}

Whole colonies of symbiotic (brown) and aposymbiotic (white) A. poculata were collected via SCUBA at Fort Wetherill State Park, Jamestown, RI (41 $1^{\circ} 28^{\prime} 40^{\prime \prime} \mathrm{N}, 71^{\circ}$ $21^{\prime} 34^{\prime \prime}$ W) in fall (September 9, 2015), winter (March 5, 2016), spring (April 29, 2016), and summer (July 19, 2016). To minimize the potential of hyper-localized environmental effects due to benthic composition, benthic orientation, or abiotic factors, we sampled colony pairs in which a brown colony occurred within $10 \mathrm{~cm}$ of a white colony. At each time point, colony pairs ranging in size from 4 to $8 \mathrm{~cm}$ total diameter were collected from $\sim 1$ to $5 \mathrm{~m}$ water depth from the same location ( $n=10$ colony pairs in each of fall, spring, and summer; $n=6$ colony pairs in winter). Immediately post-collection, subsamples of each colony were frozen in liquid nitrogen at the surface and stored at $-80{ }^{\circ} \mathrm{C}$ until DNA extraction. The remainder of each colony was transported in individual, labeled Whirl-Pak ${ }^{\circ}$ bags within a cooler of seawater back to the laboratory for immediate (within 2-3 h of collection) Symbiodinium quantification. During each collection, replicate seawater samples $(n=10$ for winter, spring, summer; $n=9$ for fall, summarized in Table 1) were collected from $\sim 1$ to $5 \mathrm{~m}$ water depth using autoclaved glass $1 \mathrm{l}$ bottles. Immediately after water collection, seawater microbes were filtered by syringe onto a Sterivex ${ }^{\mathrm{Tm}}$ cartridge $(0.2-\mu \mathrm{m}$ pore size), which was then frozen in liquid nitrogen and stored at $-80{ }^{\circ} \mathrm{C}$ until DNA extraction. Daily measurements of seawater surface temperatures (NOAA 172 Tides \& Currents, Newport, RI: site 8452660) spanning the year-long sampling period were used to assign temperature ranges to each season. Average sea surface temperatures in the four sampling periods were $22^{\circ} \mathrm{C}$ in fall, $3{ }^{\circ} \mathrm{C}$ in winter, $9{ }^{\circ} \mathrm{C}$ in spring, and $21^{\circ} \mathrm{C}$ in summer (NOAA 172 Tides \& Currents, Newport, RI: site 8452660).

\section{Symbiodinium quantification}

The relationship between polyp color and areal chlorophyll concentration has been previously established for A. poculata [32]. Here, we visually distinguished brown from white corals during collection and subsequently measured Symbiodinium density from each colony via cell counts (\# Symbiodinium cells $\mathrm{cm}^{-2}$ coral). From each colony, coral tissue was removed from the skeleton using a Waterpik [38] with $0.22-\mu \mathrm{m}$ filtered seawater, homogenized, and centrifuged to produce a pellet. Excess supernatant was removed, and pellets were suspended in a final volume of 12-15 ml. Samples were fixed in $4 \%$ zinc-formalin fixative Z-Fix (Anatech, Ltd., Battle Creek, MI) and stored at room temperature. Subsampled colony surface area was determined using aluminum foil as in Marsh [39]. Average total number of Symbiodinium cells was enumerated for each waterpiked subsample (above) using a hemocytometer $(n=4$ counts per sample replicate), with a total of five replicate subsamples counted per colony. Because the collected corals were small and the subsamples were prioritized for DNA extraction, not all colonies were used for symbiont

Table 1 Summary of collected specimens via SCUBA at Fort Wetherill State Park, Jamestown, RI $\left(41^{\circ} 28^{\prime} 40^{\prime \prime} \mathrm{N}, 71^{\circ} 21^{\prime} 34^{\prime \prime} \mathrm{W}\right)$ in Fall (9/9/15), Winter (3/5/16), Spring (4/29/16) and Summer (7/19/ 16) time points. Shown are the number of replicate specimens collected for each sample group during each time point. The total number of high-quality reads, including the high-quality reads from all seawater and all coral specimens, is shown

\begin{tabular}{llllllll}
\hline & \multicolumn{4}{l}{ Number of samples (total $=110)$} & \multirow{2}{*}{$\begin{array}{l}\text { Total } \\
\text { reall }\end{array}$} & OTUs \\
\cline { 2 - 5 } & Fall & Winter & Spring & Summer & & \\
\hline Seawater & 9 & 9 & 10 & 10 & $7,683,584$ & 37,089 \\
Brown colonies & 10 & 6 & 10 & 10 & & 28,243 \\
White colonies & 10 & 6 & 10 & 10 & & \\
\hline
\end{tabular}


quantification. Photos of each colony were taken with a color standard as previously described $[32,36]$ and were used for visual confirmation of color and symbiotic state assignment. A two-way ANOVA was used to determine the effect of collection season and colony symbiotic state ("brown" or "white") on Symbiodinium density, followed by post hoc Tukey tests.

To quantify symbiotic state across depth in the field, underwater transects were conducted in Ft. Wetherill, RI, in July 2010. Two divers were deployed along a vertical granite slope to conduct a $15-\mathrm{m}$ transect, simultaneously surveying and marking colonies as either "brown," "white," or "mixed." Every $0.6 \mathrm{~m}$ along a linear transact, $A$. poculata colonies were counted in a $0.25 \mathrm{~m}^{2}$ quadrat, centered around the transect line. All A. poculata colonies inside the quadrat were included.

\section{DNA processing}

From each $A$. poculata subsample, total DNA was extracted from a small fragment $\left(\sim 1 \mathrm{~cm}^{2}\right)$ that included coral tissue, mucus, and skeleton, using the PowerSoil $^{\bullet}$ DNA Isolation Kit (Qiagen, Valencia, CA). Each fragment (only partially thawed) was placed directly into a PowerBead tube for extraction according to the manufacturer's protocol. DNA from seawater microbes was extracted directly from the Sterive ${ }^{\mathrm{mm}}$ cartridges using a phenol:chloroform extraction method (modified from [16, 40]). Following the phenol:chloroform extraction, a second extraction was performed using the PowerSoil $^{\circ}$ DNA Isolation Kit. The V4 region of the 16S rRNA gene was amplified for all samples using F515 and R806 primers [41], with the addition of Illumina-specific adapters [42]. Final PCR reactions consisted of $22 \mu \mathrm{l}$ Platinum PCR SuperMix (ThermoFisher Scientific, Waltham, MA), $2 \mu \mathrm{l}$ DNA template, $0.5 \mu \mathrm{l}$ each of the primers $\mathrm{F} 515$ (5'-CACGGTCGKCGGCGCCATT-3') and R806 (5'GGACTACHVGGGTWTCTAAT-3') (final concentrations $0.4 \mu \mathrm{M}$ each), and $0.5 \mu \mathrm{l}$ BSA $(20 \mathrm{mg} / \mathrm{ml}$, New England BioLabs, Inc., Ipswich, MA). Amplicons were generated with an initial denaturation of $3 \mathrm{~min}$ at $94{ }^{\circ} \mathrm{C}$, followed by 30 cycles of $94{ }^{\circ} \mathrm{C}(45 \mathrm{~s}), 55{ }^{\circ} \mathrm{C}$ $(45 \mathrm{~s})$, and $72{ }^{\circ} \mathrm{C}(90 \mathrm{~s})$, with a final extension for $10 \mathrm{~min}$ at $72{ }^{\circ} \mathrm{C}$, and cleaned using Diffinity RapidTips (Chiral Technologies, Inc., West Chester, PA). All PCR products were pooled in equimolar concentration and sequenced on the Illumina MiSeq $(2 \times 250$ bp paired end $)$ with a $10 \%$ PhiX control. It is important to recognize that the primers used in the study may not have captured the full extent of microbial diversity, particularly within the Archaea. It is therefore possible that patterns of community assembly may differ among certain subsets of the microbiome if evaluated at higher levels of resolution.

\section{Sequence data analysis}

Only sequences greater than 100 bp with a Phred score greater than 25 were retained, as determined by Trim Galore!. Paired end reads were then merged using FLASH [43], imported into QIIME version 1.9.1 [44], and checked for chimeric sequences using USEARCH 6.1 against the Greengenes database release 8.15.13 [45]. After removal of chimeric sequences, taxonomy was assigned using an open-reference algorithm [46] against the Greengenes database. Reads that were not identified as "Archaeal" or "Bacterial" were removed, as well as reads that identified as "Chloroplast." An OTU table rarefied to 1000 reads was used for all analyses, with the exception of DESeq2 analysis [47] conducted through the R package Phyloseq [48], which contains an internal normalization algorithm.

\section{Taxonomic diversity analysis}

Alpha diversity was analyzed in QIIME at a uniform sequence depth $(N=1000)$ using the Shannon Index $\left(\mathrm{H}^{\prime}\right)$, Shannon Equitability $\left(\mathrm{E}_{\mathrm{H}}\right)$, Chao1, and phylogenetic diversity (PD) metrics. The Shannon Index $\left(\mathrm{H}^{\prime}\right)$ was converted to a natural log Shannon Index. Alpha diversity data were then analyzed in GraphPad Prism v6.0h for Mac OS X. A two-way ANOVA was used to determine the effect of collection season and colony symbiotic state ("brown" or "white") on coral microbial alpha diversity, and a one-way ANOVA was used to analyze the effect of collection season on seawater microbial alpha diversity. Similarity in community composition was tested via ANOSIM and PERMANOVA in QIIME using 999 permutations. Variation in community composition (beta diversity) among samples was visualized via non-metric multidimensional scaling (NMDS) ordination based on Bray-Curtis dissimilarity matrices, using the VEGAN package [49].

\section{Results \\ Symbiodinium psygmophilum densities and facultative symbiosis in $A$. poculata}

Cell counts were used to measure Symbiodinium cell density from colonies that were visually assessed as "brown" or "white" corals during collection. Two-way ANOVA demonstrated that both season and colony color were correlated with Symbiodinium density (Additional file 1). However, the magnitude of seasonal variation differed between brown and white corals. Post hoc Tukey tests demonstrated that Symbiodinium density did not differ across seasons in white colonies. In contrast, brown colonies exhibited significantly higher Symbiodinium density in summer compared to other seasons, which did not differ from one another (Fig. 1c). Notably, Symbiodinium density in brown colonies increased an order of magnitude from winter $\left(1.8 \times 10^{6}\right.$ 
cells $\left./ \mathrm{cm}^{2}\right)$ to summer $\left(1.9 \times 10^{7}\right.$ cells $/ \mathrm{cm}^{2}$; Fig. $\left.1 \mathrm{c}\right)$. During summer, brown colonies also exhibited significantly higher Symbiodinium density compared to white colonies. Adjacent A. poculata colonies displayed different symbiotic states even at the same depth within a site (Additional file 2).

\section{Astrangia poculata and seawater microbiome sequence statistics}

Small subunit ribosomal RNA (16S rRNA) gene amplicons from a total of 110 coral and seawater specimens were sequenced (summarized in Table 1). At each seasonal time point, whole coral colony material (skeleton, tissue, and mucus together) was collected from both brown and white colonies, and seawater samples were collected. Sequencing of these samples produced 7,683,584 high-quality sequence reads, which were clustered into operational taxonomic units (OTUs) based on $97 \%$ sequence similarity. Fifty thousand seven hundred fifty of the total 51,213 OTUs were affiliated with members of the domain Bacteria, and 463 of the OTUs were affiliated with the domain Archaea. Coral and seawater specimens harbored a total of 28,243 and 37,089 OTUs, respectively.

\section{Influence of seasonality and seawater on A. poculata microbiome diversity}

Two-way ANOVA analysis of four indices of alpha diversity, including Chao1, Shannon Diversity $\left(\mathrm{H}^{\prime}\right)$ and Equitability $\left(\mathrm{E}_{\mathrm{H}}\right)$, and phylogenetic diversity (PD), demonstrated a significant influence of season on coral microbial alpha diversity (Fig. 2, two-way ANOVA; H' $p=0.015 ; \mathrm{E}_{\mathrm{H}} p=0.052 ; \mathrm{PD} p=0.001$; Chao1 $p=0.006$ ), with both $\mathrm{H}^{\prime}$ and $\mathrm{E}_{\mathrm{H}}$ metrics based on a combination of richness and evenness, PD expressing overall phylogenetic diversity in the community, and Chaol estimating richness by taking into account the number of rare OTUs present in the community. Post hoc Tukey tests revealed that spring white $A$. poculata colonies exhibited significantly increased $\mathrm{H}^{\prime}, \mathrm{E}_{\mathrm{H}}$, and $\mathrm{PD}$ compared to all other sample types. The influence of rare OTUs (Chao1) in spring white colonies was similar to that in summer white and spring brown colonies. In contrast, the microbiomes of winter white colonies had lower levels of phylogenetic diversity and a smaller number of rare OTUs compared to almost all other sample types. Fall and summer brown colonies were significantly lower in richness and evenness $\left(\mathrm{H}^{\prime}\right)$ compared to other sample types, while summer brown colonies also had a relatively smaller number of rare OTUs compared to those of most other sample types (with the exception of winter whites, Fig. 2).

One-way ANOVA analysis of multiple indices of alpha diversity demonstrated that season significantly impacts seawater microbial alpha diversity (Fig. 3, one-way ANOVA; $\left.\mathrm{H}^{\prime} p=0.342, \mathrm{E}_{\mathrm{H}} / \mathrm{PD} / \mathrm{Chao} 1 p<0.0001\right)$. However, the seasonal effect varied depending on the metric and did not parallel the trend observed in coral. While seawater $\mathrm{H}^{\prime}$ values did not vary among seasons, $\mathrm{E}_{\mathrm{H}}$ values (equitability) of winter, spring, and summer
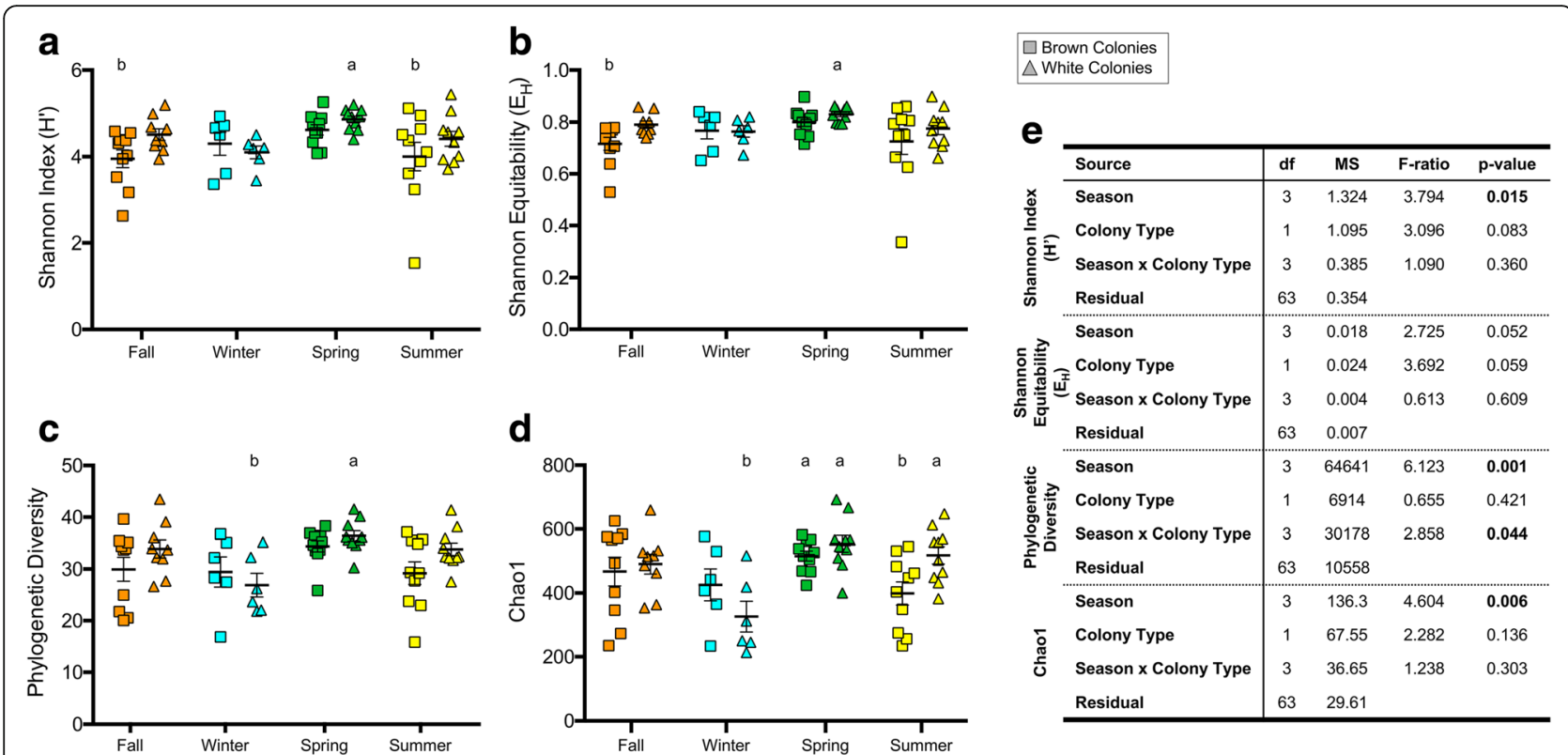

Fig. 2 Alpha diversity metrics of brown and white colonies. All indices are highest for white colonies collected during the spring (a-d). Two-way ANOVA demonstrated that collection season but not colony type affected coral microbial alpha diversity (e). Bolded $p$ values were significant $(p<0.05)$. Results from a post hoc Tukey test are presented as letters $(\mathbf{a}, \mathbf{b})$ denoting groups that are significantly different. Columns that lack letters are not significantly different 


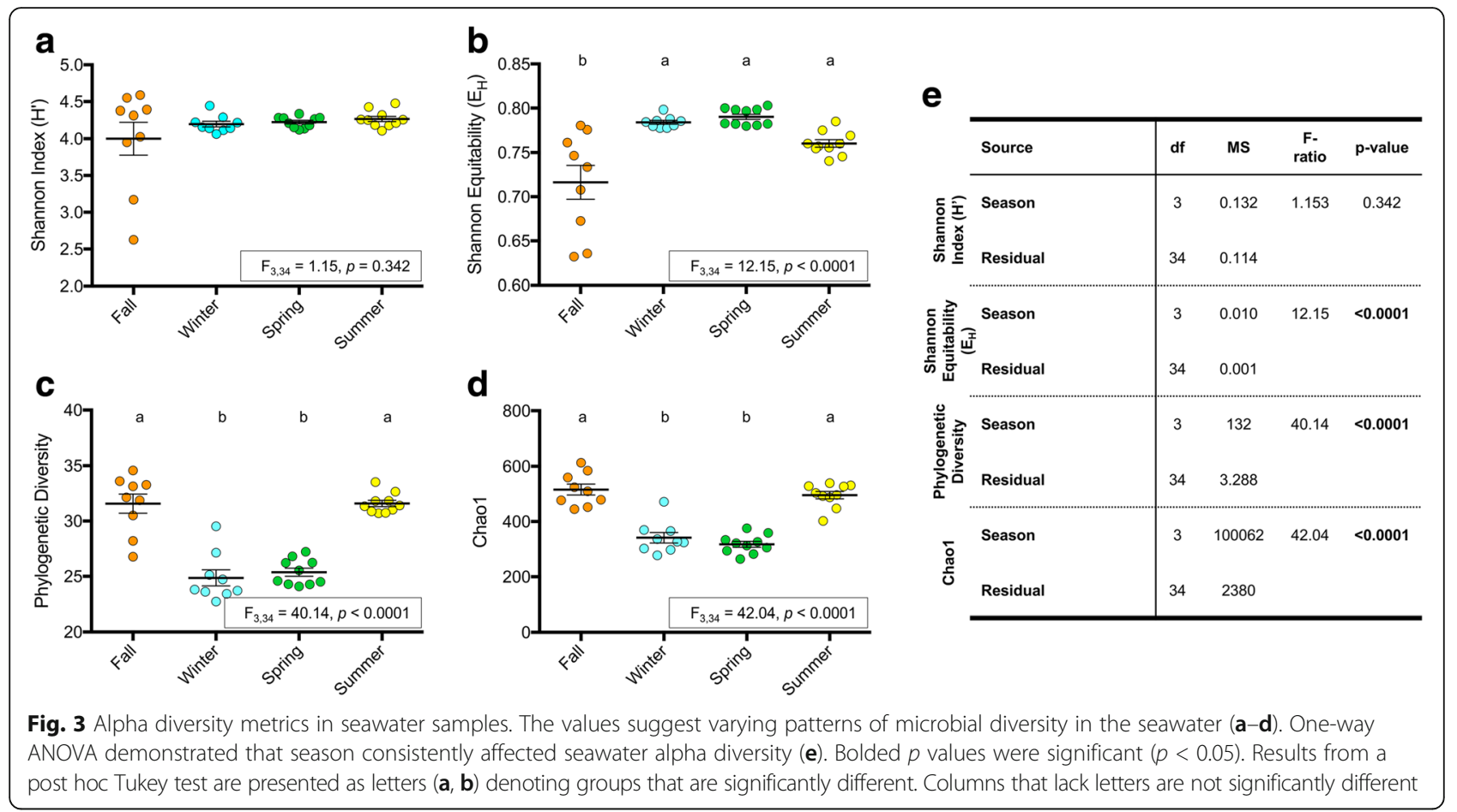

seawater communities were similar and significantly higher than those in fall (post hoc Tukey tests, Fig. 3). In contrast, seawater PD and Chao1 values exhibited the opposite pattern, being significantly higher in summer and fall compared to winter and spring. Thus, compared to winter and spring communities, summer and fall seawater microbiomes were less even, with total richness affected less by rare taxa, potentially consistent with dominance by a subset of active community members.

Both A. poculata microbiome composition (Fig. 4a, ANOSIM $R=0.229, p=0.001$, PERMANOVA, $F=2.91$, $p=0.001$ ) and seawater microbiome composition (Fig. 4b,
ANOSIM $R=1.0, p=0.001$, PERMANOVA, $F=78.01$, $p=0.001$ ) varied significantly across seasonal time points. This variation was notably higher in the seawater, with seawater samples partitioning into non-overlapping NMDS clusters based on season (Fig. 4a, b). Both brown and white $A$. poculata microbiomes differed significantly from seawater microbiomes when the data from all seasons were grouped (Fig. 4c; ANOSIM $R=0.684$, $p=0.001$, PERMANOVA, $F=18.51, p=0.001)$ and when evaluated independently by season (Fig. 5a-d; ANOSIM $R=0.772-0.960, p=0.001$, PERMANOVA, $F=14.62$ 23.09, $p=0.001$ ), suggesting minimal effects of seawater
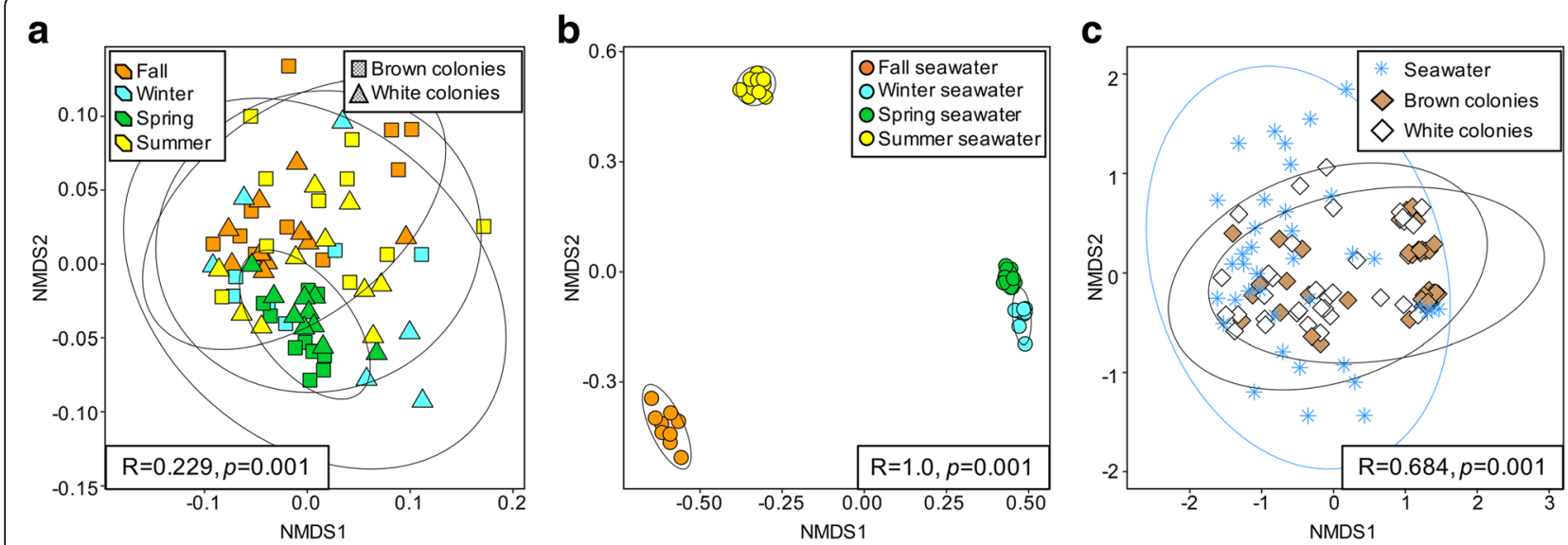

Fig. 4 NMDS visualizations of beta diversity analysis using the Bray-Curtis metric. Ellipses represent 95\% confidence intervals. ANOSIM (boxes within NMDS plots) also revealed significant dissimilarity between groupings of coral samples from the four seasonal time points (a), of seawater samples from the four seasonal time points (b), and of brown colonies, white colonies, and seawater (c) 

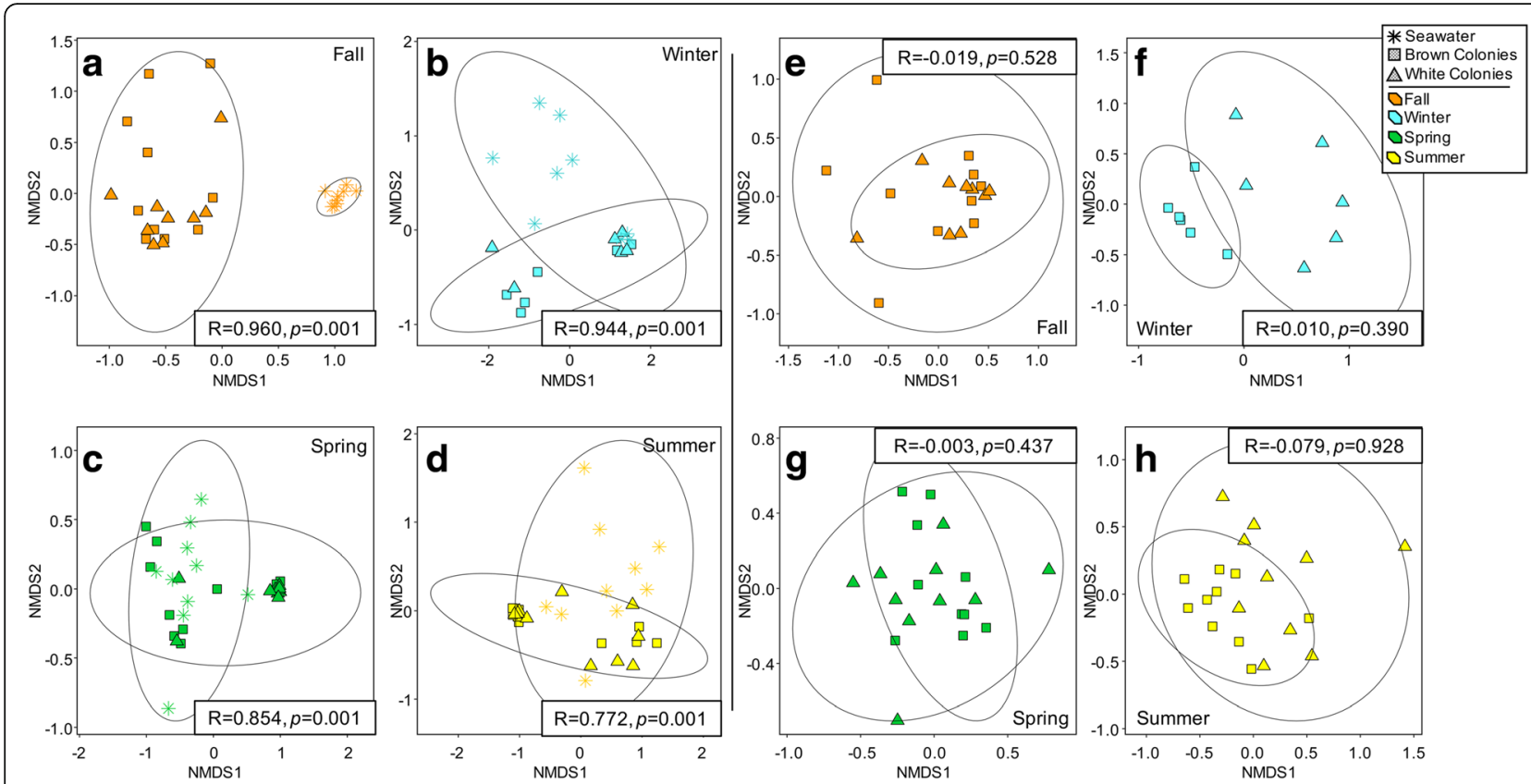

Fig. 5 NMDS visualizations of beta diversity analysis using the Bray-Curtis metric separating samples by collection season. Ellipses represent 95\% confidence intervals for coral versus seawater samples (a-d) or for brown versus white colonies (e-h). In each seasonal time point, ANOSIM (boxes within NMDS plots) did not reveal significant dissimilarity between symbiotic state of colonies but did reveal significant dissimilarity between corals and seawater

microbiomes on coral microbiome composition. While the coral microbiome substantially overlaps with that of the seawater microbiome, it appears to be comparatively restricted (lower dispersion, Fig. 4c). However, the level of relatedness between coral and seawater microbiomes varied among seasons, with coral and seawater communities being least similar in the fall (ANOSIM $R=0.960$, $p=0.001$, PERMANOVA, $F=17.48, p=0.001)$ and most similar in summer (ANOSIM $R=0.772, p=0.001$, PERMANOVA, $F=14.62, p=0.001$, Fig. 5a-d). Conversely, the spring coral and seawater microbiomes were found to be the least similar by the PERMANOVA metric $(F=23.09, p=0.001$, ANOSIM $R=0.854, p=0.001)$, likely due to the lower dispersion of the spring coral samples, to which PERMANOVA is more sensitive.

Springtime coral microbiomes were distinct from those in other seasons. Removal of the spring data revealed only slight differences in coral microbiome composition among the other three seasons (Additional file 3, ANOSIM $R=0.135, p=0.002$, PERMANOVA $F=2.04, p=0.001$ ). Furthermore, although non-overlapping season-specific clusters were not observed in NMDS analysis of the $A$. poculata microbiomes (Fig. 4a), those from the spring were most similar to one another, exhibiting the lowest inter-sample variability (dispersion) compared to other seasons. Together, these patterns indicate a relative uniformity of coral microbiomes during spring and that a shift in coral microbiome composition during this period contributed substantially to the overall seasonal variation.

\section{Influence of symbiotic state on A. poculata microbiome composition}

In contrast to results based on season, and to our expectations, two-way ANOVA analysis of four indices of alpha diversity did not demonstrate a strong influence of symbiont state (brown or white) on A poculata microbiomes (Fig. 2). A significant difference in alpha diversity between brown and white colonies was observed only for the Chao1 metric (Fig. 2d) and only during summer when Symbiodinium density differed the most between brown and white colonies (Fig. 1c). For all other metrics and seasons, alpha diversity of $A$. poculata microbiomes did not differ between brown and white colonies (Fig. 2, two-way ANOVA; $\mathrm{H}^{\prime} p=0.083 ; \mathrm{E}_{\mathrm{H}} p=0.059 ; \mathrm{PD}$ $p=0.421$; Chao1 $p=0.136$ ). Furthermore, symbiotic state had no perceivable effect on taxonomic composition of the microbiome. For each of the four time points, ANOSIM detected no dissimilarity in microbiome composition between brown and white $\mathrm{A}$. poculata individuals from the same time point (Fig. $5 \mathrm{e}-\mathrm{h}$, for all, ANOSIM $R<0.01, p>0.3$, PERMANOVA, $F<1.06$, $p>0.34$ ). When season was removed from the analysis, no dissimilarity was found between all brown and all white $A$. poculata individuals (ANOSIM $R=-0.014$, $p=0.844$, PERMANOVA, $F=0.83, p=0.746$ ).

\section{Dominant microbiome taxa}

OTUs from this $A$. poculata specimen collection, spanning the four seasonal time points and regardless of symbiotic state, consistently were dominated by six main 
classes or phyla of prokaryotes: the $\gamma$-proteobacteria, $\alpha$-proteobacteria, $\delta$-proteobacteria, $\quad$ Flavobacteriia, Cytophagia, and Thaumarchaea (Fig. 6). In the seawater samples, three main classes ( $\gamma$-proteobacteria, $\alpha$ proteobacteria, and Flavobacteriia) were consistently the most abundant. More $\gamma$-proteobacterial orders were present in the $A$. poculata samples than in the seawater (Fig. 7). Notably, in all seasons, the $\gamma$-proteobacteria from the corals and the seawater consisted primarily of Alteromonadales and Oceanospirillales, both of which have been implicated in dimethylsulfoniopropionate (DMSP) and polysaccharide degradation in other coral species [50,51]. Other abundant OTUs in the coral samples included those affiliated with the Chromatiales, Vibrionales, and Thiohalorhabdales. The coral samples also possessed higher order-level richness within the $\alpha$-proteobacteria, compared to those in the seawater (Fig. 7). The majority of the $\alpha$-proteobacterial sequences from both coral and seawater samples were consistently Rhodobacterales and an unclassified $\alpha$-proteobacterium $(10 \%$ on average in corals; $3-10 \%$ in seawater). OTUs representing Rhizobiales, Rhodospirillales, and Sphingomonadales, which made up more than $5 \%$ of the OTUs from the coral samples, were detected in the seawater samples, but they made up less than $1 \%$ of the OTUs from the seawater.
The coral samples consistently had a higher proportion of OTUs representing $\delta$-proteobacteria $(2-11 \%$ of OTUs) compared to the seawater samples (less than $2 \%$ of OTUs). These OTUs were primarily Desulfobacterales and Myxococcales (Fig. 7). Other $\delta$-proteobacterial orders consistently present in the corals included Entotheonellales, which has been observed previously in a diversity of marine sponges [52, 53], and the candidate division NB1-j, documented previously in tropical hard corals [54]. A single OTU representing the Thaumarchaeota genus Nitrosopumilus, which never contributed to more than $0.2 \%$ of the sequences in the seawater samples, was detected in $100 \%$ of $A$. poculata samples and averaged $8 \%$ of the sequences $(1 \%-36 \%$ of the sequences in a given sample). This Thaumarchaeota OTU did not vary significantly in relative abundance (DESeq2 analysis) according to season or A. poculata symbiotic state (see Additional file 4). Cytophagia sequences recovered from the corals similarly represented few genera, and a majority fell within the genus Amoebophilus (Fig. 7), previously proposed as a symbiont of Symbiodinium within the tropical coral Pocillopora meandrina [55]. Flavobacteriia sequences exhibited lower relative abundance in corals $(5-14 \%$ of total sequences) compared to seawater (17-36\%, Fig. 7). Flavobacteriia sequences, $50 \%$ of which belonged to the same

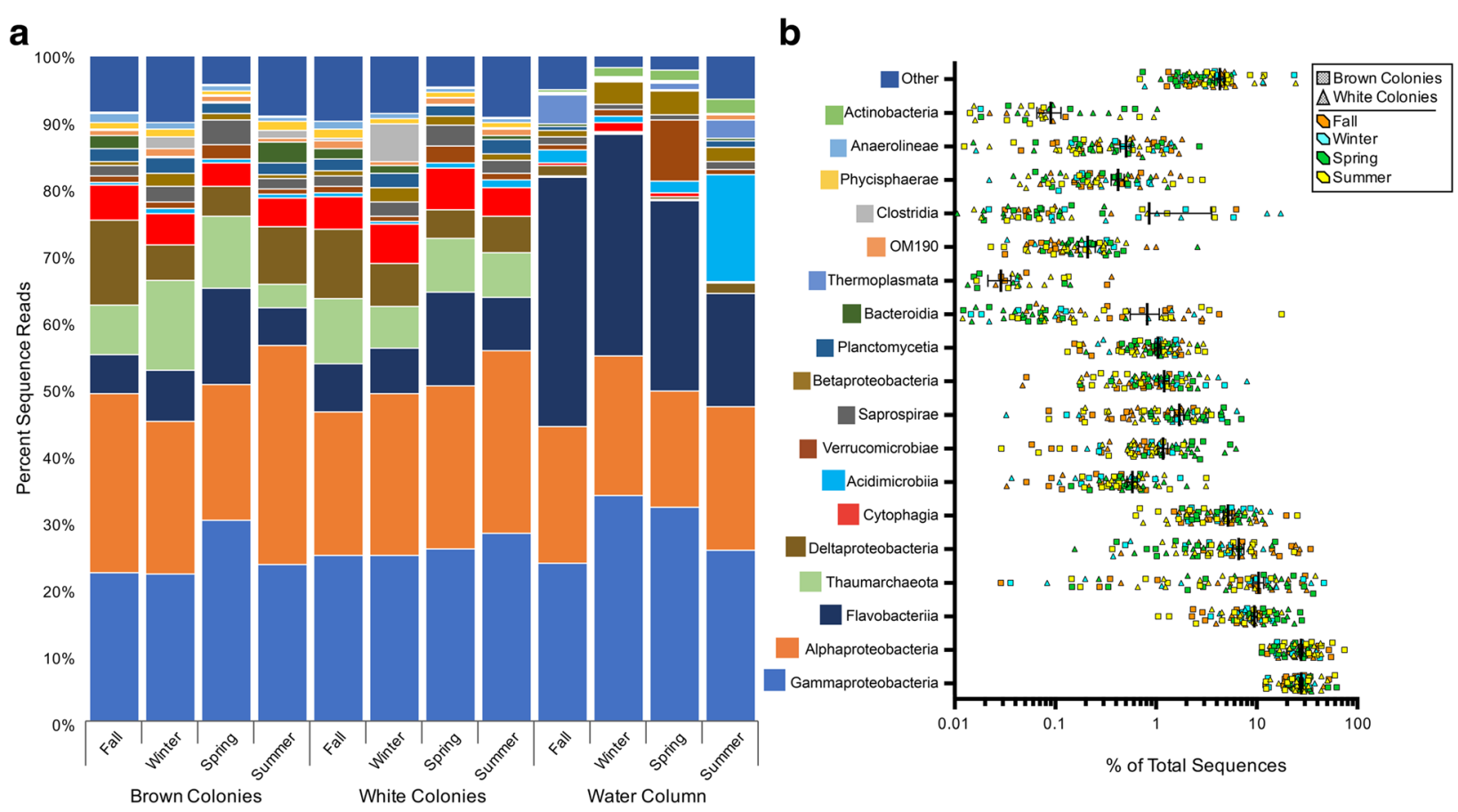

Fig. 6 Taxonomic composition of the A. poculata and seawater microbiomes at the prokaryotic class level, according to 165 sequence analysis. (a) Coral microbiomes are dominated by six prokaryotic classes, and the seawater microbiomes are dominated by three of the same classes, exhibiting more seasonal variation. Bars represent mean abundance ( $n=10$ A. poculata colonies in fall, spring, summer; $n=6$ colonies in winter; $n=10$ seawater samples in all four time points) of each class. (b) Variation in relative abundance of each prokaryotic class in the samples. Relative abundance of each prokaryotic class in the coral microbiomes vary by sample, but not by season or colony type. Taxa present at greater than 1\% of the average community are shown. Mean \% of total sequences is represented by thick bar, and standard error is represented by thin bars. Scatter plot presented on a log scale to cover range of variation across all classes 


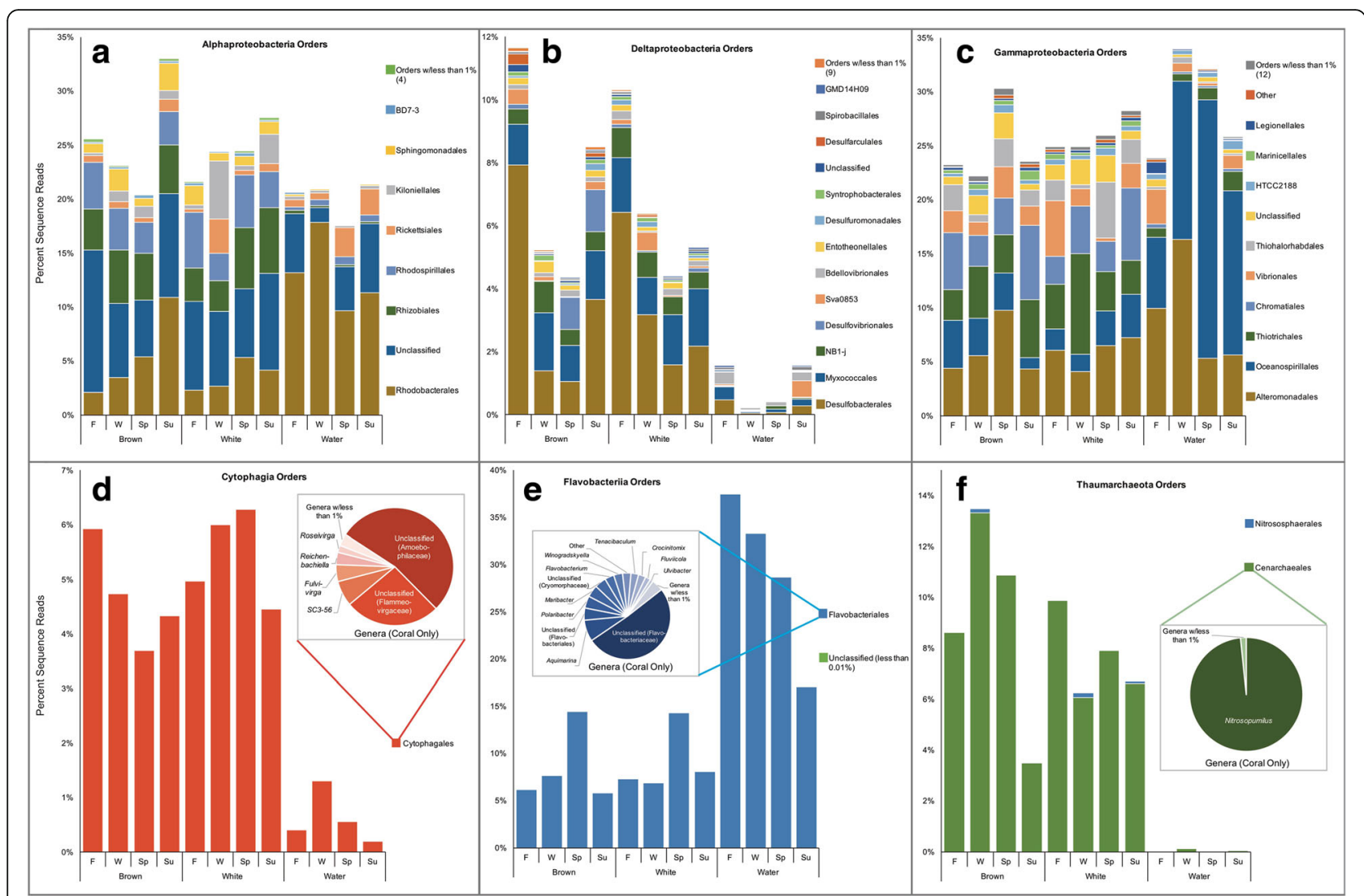

Fig. 7 Taxonomic composition of the six most abundant prokaryotic classes from all sample types. Bars represent mean abundance $(n=10$ for $A$. poculata colonies in fall, spring, summer; $n=6$ colonies in winter; $n=10$ for seawater in all four time points). Taxonomic resolution for each class is further broken down to order $(\mathbf{a}-\mathbf{c})$ or genus $(\mathbf{d}-\mathbf{f})$ level

genus (unclassified), spiked in abundance during the spring time point, both in brown and white symbiotic states. Of approximately 28,000 unique OTUs recovered from A. poculata samples, 97 were present in $\geq 90 \%$ of samples (see Additional file 5), while only 25 OTUs were present across all $A$. poculata samples.

\section{Microbiome taxa differing in relative abundance by season}

The seasonal shifts in the composition of $A$. poculata and seawater microbiomes involved changes in the relative abundance of specific taxa. DESeq2 analysis identified 181 genera whose relative abundance changed significantly in at least one pairwise comparison between seasonal datasets. Compared to $A$. poculata microbiomes from the winter time point, those of the spring time point were significantly enriched in several taxa commonly affiliated with corals (see Additional file 4), including Oceanospirillaceae, Flavobacteriaceae, Microbacteriaceae, Rhodobacteraceae, Bdellovibrionaceae, Alteromonadaceae, and Verrucomicrobiaceae. Notably, one of the Oceanospirillaceae OTUs enriched in the spring belongs to the genus Portiera, a genus first described as an endosymbiont in whiteflies [56] and since detected in coral mucus samples in the Florida
Reef Tract [57]. The enrichment of Verrucomicrobiaceae sequences from corals in the spring time point is consistent with a seasonal increase in Verrucomicrobiaceae in the seawater samples (Fig. 6). However, a clear connection to the seawater community was not evident for other taxa enriched in springtime corals. For example, members of the Flavobacteriales, though enriched in $A$. poculata in the spring, did not vary in relative abundance in seawater across seasons. The DESeq2 analysis indicated that Clostridiales, Burkholderiaceae, and Xenococcaceae were enriched in the wintertime relative to other seasons. In addition, from winter to spring, OTUs from several groups, including the Vibrionaceae, Alteromonadaceae, and Rickettsiaceae decreased in relative abundance (see Additional file 4). Like Vibrionaceae and Alteromonadaceae, Rickettsiaceae is a bacterial family containing functionally diverse organisms, including several described pathogens. However, this group has also been detected widely in putatively healthy tropical corals [58, 59]. The $A$. poculata microbiome exhibited significant relative increases in members of the Bacteroidales, Clostridiales, and Synechococcus from spring to summer time points, whereas the relative abundance of 
Rhodobacteraceae, Rickettsiaceae, and Verrucomicrobiaceae decreased significantly in the summer (see Additional file 4).

\section{Discussion}

This study sampled a temperate, naturally facultative symbiotic coral (Astrangia poculata) across seasons to test whether symbiotic state (density of the symbiont Symbiodinium psygmophilum in the coral tissue) structures the coral-associated microbiome. Determining how the presence, concentration, and activity of Symbiodinium affects microbiomes in tropical corals has been challenging because the loss of symbionts (bleaching) constitutes a significant stress to most tropical corals, often resulting in coral death, thereby preventing experimental manipulation of symbiotic state. To our knowledge, our study is the first to decouple coral-Symbiodinium symbiosis from seasonal variation to explore the microbiome response in situ. Both brown and white colonies of $A$. poculata harbor microbiomes with taxonomic diversity and composition distinct from that of the surrounding seawater (Fig. 4c). Although we observed differences in alpha diversity between brown and white colonies at some time points, notably in the summer (Fig. 2), within each of the four seasons, microbiome composition was comparatively uniform between symbiotic and aposymbiotic corals (Fig. 4). This was true even in the summer when Symbiodinum density was significantly higher in brown colonies. In contrast, microbiome composition exhibited significant shifts across seasons, due mostly to differences associated with the spring time point (Additional file 3, Fig. 4a). Thus, factors that vary with season, other than symbiotic state, are primary determinants of microbiome structure in A. poculata.

\section{Symbiotic state versus other seasonal effects}

The finding that symbiotic state has a relatively minor effect on cnidarian microbiome structure is inconsistent with prior studies. Experiments involving the facultatively symbiotic anemone Aiptasia recently revealed significant differences in microbiome composition between symbiotic versus aposymbiotic individuals reared in the laboratory [60]. In tropical and subtropical anemones and corals, Symbiodinium activity levels have been suggested as a driver of coral microbiome composition [61, 62], and the release of excess Symbiodinium photosynthate is thought to regulate microbiome composition in the mucus layer $[63,64]$. In $A$. poculata, it is unknown if excess photosynthate is released to the mucus layer. Indeed, recent studies examining wound regeneration dynamics in A. poculata provide evidence that energy may be stored in the deep-bodied polyps. Central recovery, rather than perimeter recovery, was the dominant mode of polyp regeneration in $A$. poculata, demonstrating relatively high-energy reserves on a per-polyp basis [35, 36]. It is also possible that Symbiodinium psygmophilum photosynthesis in A. poculata does not constitute a major supply of organic matter for either the microbiome or the host, even during the warmest summer months. Dimond and Carrington [32] showed that heterotrophic feeding on organic particles was the main form of carbon acquisition even in symbiotic A. poculata, with pigmentation (symbiotic state) explaining only $23 \%$ of the variation in host growth rate. Given the high reliance of $A$. poculata on particle ingestion, microbiome members may respond to changes in host heterotrophic intake and waste nutrient availability, rather than differential levels of Symbiodinium growth rate, density, or pigmentation.

Given the similarity of symbiotic versus aposymbiotic A. poculata microbiomes and the lack of similarity between coral and seawater microbiome composition at each time point (Fig. 4), the seasonal fluctuation in $A$. poculata microbiomes is likely due to factors other than Symbiodinium density or changes in water column microbiomes. Such factors could include shifts in host physiology associated with the transition to quiescence in winter months and emergence from quiescence during the spring months. During cold temperatures and winter quiescence, $A$. poculata retracts its polyps and becomes unresponsive to touch [32, 33], feeds less, loses biomass, and allocates less energy to growth, regeneration, and repair [35]. It is possible that springtime emergence of the holobiont from quiescence, which includes an increase in host feeding [33] and therefore presumably changes in host energy allocation and substrate supply for microbial growth, could drive a significant re-structuring of the microbiome. In our study, microbiomes from the A. poculata colonies collected in the spring exhibited the highest alpha diversity (Fig. 2) and the lowest inter-individual beta diversity (Fig. 4a), indicating that in the spring, A. poculata harbors a diverse but predictably structured microbiome relative to communities from the other seasonal time points. In contrast, inter-individual beta diversity in seawater samples varied little between winter and spring, suggesting that the decline in beta diversity in the spring A. poculata microbiomes does not simply reflect a seasonal change in microbial composition in the overlying seawater. Previous studies in other systems have shown that seasonal shifts and phenological timing have covaried with microbiome composition $[65,66]$ and that increased beta diversity of complex host-associated microbiomes may reflect a response to disturbance or an overall destabilization of the microbiome from one 
configuration, or stable state, to another. This pattern has been demonstrated in corals [54, 67] and in mammals $[68,69]$. Taken together, these results raise the possibility that the microbiome of $A$. poculata shifts significantly in response to the transition from quiescence to holobiont activity in spring. This transition appears to homogenize microbiome structure across individuals, potentially reflecting a conserved functional response of the microbiome to an increase in holobiont metabolic rates, and is consistent with the recent observation of periodic microbiome succession in the tropical coral Porites astreoides in response to cyclical mucus shedding [70].

\section{Microbiome members}

The seasonal shifts in A. poculata microbiome composition primarily involved changes in the relative abundance of common bacterial classes. This pattern is consistent with recent assertions that microbiomes respond to stress or disturbance through communitylevel shifts in proportional representation, rather than the disappearance or appearance of specific taxa, including pathogens $[26,67]$. Notably, the wintertime $A$. poculata microbiome was enriched in Clostridiaceae, Oscillatoriaceae, and Rickettsiaceae, but contained fewer Oceanospirillaceae relative to other seasons. Similar trends have been proposed as indicators of a wide range of disturbances in tropical corals, including nutrient enrichment and temperature increases $[26,27,67]$. However, the winter populations of $A$. poculata sampled in this study did not exhibit signs of disease, and $A$. poculata has been documented to survive quiescence during extended periods of extreme low winter temperatures [32]. Thus, the A. poculata wintertime microbiome likely does not reflect a disease state, but potentially a general "dysbiosis" due to meta-organism quiescence or lack of host metabolic activity that serves to regulate microbiome structure (as described in [71]). It is therefore feasible that what has been observed as diseaseassociated microbiome signatures (i.e., the "pathobiome"; (reviewed in [72])) in tropical corals may instead be indicators of loss of regulation by the meta-organism or a lack of restriction of microbial opportunists that are not typically a significant portion of the coral's core microbiome.

In $A$. poculata, as in coral-microbe associations in general, the proportion of detected microbial taxa that are functionally significant to the holobiont is not known. Of the nearly 200,000 OTUs detected from mucus, tissue, and skeleton of the tropical coral Pachyseris speciosa, only nine bacterial taxa were detected in $\geq 90 \%$ of the tested colonies [73]. Such studies suggest that the vast majority of coral microbiome-derived sequences are from taxa that exhibit varying degrees of host association, although the enzymes encoded by these taxa may contribute to a core set of biochemical pathways intrinsic to holobiont function. Among the 25 OTUs that were present across all $A$. poculata samples (Additional file 5), a single OTU was classified as belonging to the ammonia-oxidizing archaeal genus Nitrosopumilus, which has previously been shown to be significant to nitrogen cycling in sponges, corals, and coral reef sand and sediment [74-76]. Also present in $100 \%$ of coral samples were OTUs representing Amoebophilaceae, Pirellulaceae, and Plancomycetaceae, although the latter two families were present in very low abundance. Amoebophilaceae sequences were more abundant. This family has been found previously in corals and hypothesized to include symbionts of Symbiodinium or other protists in the coral holobiont [55]. The Amoebophilus and Nitrosopumilus OTUs recovered here did not change significantly in relative abundance across seasons, indicating that they may be stable, functionally significant members of the $A$. poculata microbiome. Although Amoebophilus sp. has been proposed as a Symbiodinium associate in tropical corals, in A. poculata, this OTU is not enriched in brown colonies. An OTU of the genus Endozoicomonas, which has been recovered from a wide variety of cnidarians and other invertebrates and also shown to occur in aggregates within coral tissue $[15,55]$, was recovered across $94 \%$ of the A. poculata samples. Together, the OTUs common across our coral samples may be targets for further study to better understand functional contributions of the $A$. poculata core microbiome. Recent studies suggest that microhabitats or niches within corals (i.e., the mucopolysaccharide layer, tissue, and skeleton) harbor specific microbial communities [77]. In this study, the microbiome of the entire coral was examined, with all potentially distinct microhabitats pooled together. Future research that focuses on the microbiomes of separate microhabitats within a single colony would provide useful insight into the potential stability and function of key microbiome players.

\section{Comparison with tropical corals}

The A. poculata colonies in this study, taken from the northern edge of the species range [78], exhibited lower alpha diversity than has been documented in tropical corals via comparable sequencing methods. For example, Chao1 richness estimates in colonies of the Great Barrier Reef coral Pachyseris speciosa range from 700 to 1500 OTUs [73]. In contrast, the average Chaol estimate in the A. poculata microbiomes was $471( \pm 118)$, ranging from 213 to 692. Notably, alpha diversity of cold, deepwater corals has been shown to be even lower [79]. Furthermore, within each seasonal time point, overall microbiome composition in $A$. poculata was remarkably 
uniform between samples, a pattern that also differs from that of tropical scleractinian coral microbiomes [80]. It is possible that emergence from quiescence may catalyze an annual "re-organization" of the A. poculata microbiome each spring. Drastic fluctuations in environmental parameters, including temperature and levels of nutrients or organic carbon might also drive cyclical microbiome community succession, including the spring re-organization. It is possible that such reorganization, regardless of its cause, resets the coral microbiome annually, resulting in the observed high levels of stability in the microbiome. This pattern would not be expected in tropical corals, which do not undergo a dormant phase.

\section{Conclusions}

Here, the facultative nature of the A. poculata-S. psygmophilum symbiosis has enabled us to distinguish the role of season from the role of symbiosis in structuring the coral microbiome. Although seasonal shifts in $A$. poculata microbiome composition do occur, our data suggest that they are not due to fluctuation in Symbiodinium density. We observed a re-structuring of the A. poculata microbiome upon transition from winter to spring, during which time microbiome composition became more similar among host individuals. This pattern raises the hypothesis that the microbiome undergoes succession correlated with season, potentially including a shift from a destabilized microbiome in quiescent colonies during the coldest winter months, followed by a re-structuring in the spring as temperatures rise and holobiont activity resumes. At the microbial class level, $A$. poculata microbiomes are similar to those in tropical corals, being dominated, for example, by $\gamma^{-}$and $\alpha$-proteobacteria, with Cytophagia, Flavobacteriia, $\delta$-proteobacteria, and Thaumarchaea present at lower abundances. These trends suggest potential similarities in microbial metabolic profiles and contributions to holobiont function, although this hypothesis requires further testing. Future studies should extend across the entire range of A. poculata, including corals from regions that experience less extreme seasonal fluctuations in temperature and nutrient/organic matter levels. Indeed, it is not yet known if quiescence occurs in southern populations of $A$. poculata. Studies in regions where $A$. poculata occurs with tropical corals (e.g., the Gulf of Mexico) will enable direct comparisons of microbiome organization drivers across diverse hosts, potentially helping to identify unifying principles of microbiome assembly. The importance of phenology in the stability of coral microbiomes, both temperate and tropical, will become increasingly important under climate change [81]. A continued increase in the severity and frequency of high-temperature periods on tropical reefs, which have otherwise not historically experienced wide temperature fluctuations, could drastically alter the ability of corals to regulate microbiome composition.

\section{Additional files}

Additional file 1: Two-way ANOVA demonstrating that both seasonal time point and symbiotic state affect Symbiodinium density. (XLSX 34 kb)

Additional file 2: Distribution of A. poculata colonies at Ft. Wetherill, Rl, surveyed in July. Symbiotic (brown), aposymbiotic (white), and mixed (hashed) colonies occur in close proximity, not stratified by depth. (TIF $677 \mathrm{~kb}$ )

Additional file 3: NMDS visualizations of beta diversity among coral samples from summer, fall, and winter time points only. NMDS clustering is based on the Bray-Curtis dissimilarity metrics. Ellipses represent 95\% confidence intervals. ANOSIM (box within NMDS plots) also revealed significant dissimilarity between groupings of coral samples from the three seasonal time points (A), although these differences were slight. (XLSX $709 \mathrm{~kb}$ )

Additional file 4: DESeq2 analysis results, showing $\log _{2}$ fold-change values for genera that exhibited significant shifts in relative abundance from one season to another. Genera that were represented by five or fewer reads across all coral samples were removed from analysis. A total of 181 genera show a significant difference in at least one of the seasonto-season comparisons. A positive value indicates a decrease in abundance from the first season to the next; a negative value indicates an increase in abundance from the first season to the next. (XLSX 58 kb)

Additional file 5: OTUs consistently detected in $\geq 90 \%$ of Astrangia poculata colonies in this study. OTUs identified to the lowest taxonomic level possible, with corresponding percentage of occurrence within the test samples from this study. (XLSX $12 \mathrm{~kb}$ )

\section{Acknowledgements}

The authors extend appreciation to the annual Astrangia Workshop hosted by Roger Williams University for fostering creative conversations and collaborations leading to this work. Astrangia poculata specimen collection was done in accordance with the Rhode Island Department of Environmental Management Scientific Collector's Permit, issued to Roger Williams University (permits \#2015-03G and \#2016-03E), and was assigned IACUC \#2013-04 by the New England Aquarium. We thank Lydia Glenn, Sean Costello, and David Wedge (New England Aquarium) for assistance in collection via SCUBA, Christopher Marks for assistance with Astrangia colony distribution data collection, and Alex Huhman and Shelby Gantt for help in molecular analyses, and Felicia Greco, Erin Borbee, Alexis VanDruff, and Nathan Zaccardi for assistance in Symbiodinium quantification.

\section{Funding}

This work was funded in part by the Roger Williams University Fund for Promotion of Scholarship \& Teaching (to KS) and by Simons Foundation award 346253 (to FJS)

\section{Availability of data and materials}

All sequence data generated in this study have been deposited in the NCBI Sequence Read Archive under BioProject ID PRJNA380119.

\section{Authors' contributions}

$K S, Z P, A K, R R$, and FS contributed to the study design, data interpretation, and manuscript preparation. All authors read and approved the final manuscript.

Ethics approval and consent to participate Not applicable. 


\section{Competing interests}

The authors declare that they have no competing interests.

\section{Publisher's Note}

Springer Nature remains neutral with regard to jurisdictional claims in published maps and institutional affiliations.

\section{Author details}

'Department of Biology, Marine Biology and Environmental Science, Roger Williams University, 1 Old Ferry Road, Bristol, RI 02809, USA. ² Georgia Institute of Technology, Atlanta, USA. 'University of Connecticut, Storrs, CT, USA ${ }^{4}$ Boston University, Boston, USA. ${ }^{5}$ New England Aquarium, Boston, USA.

Received: 27 March 2017 Accepted: 20 August 2017 Published online: 15 September 2017

\section{References}

1. Ainsworth TD, Gates RD. Corals' microbial sentinels. Science. 2016;352:1518-9.

2. Bosch TC, McFall-Ngai MJ. Metaorganisms as the new frontier. Zoology (Jena). 2011:114:185-90.

3. Knowlton N, Rohwer F. Multispecies microbial mutualisms on coral reefs: the host as a habitat. Am Nat. 2003;162:S51-62.

4. Lesser MP, Falcon LI, Rodriguez-Roman A, Enriquez S, Hoegh-Guldberg O, Iglesias-Prieto R. Nitrogen fixation by symbiotic cyanobacteria provides a source of nitrogen for the scleractinian coral Montastraea cavernosa. Mar Ecol Prog Ser. 2007;346:143-52.

5. Olson ND, Ainsworth TD, Gates RD, Takabayashi M. Diazotrophic bacteria associated with Hawaiian Montipora corals: diversity and abundance in correlation with symbiotic dinoflagellates. J Exp Mar Biol Ecol. 2009;371:1406.

6. Nissimov J, Rosenberg E, Munn CB. Antimicrobial properties of resident coral mucus bacteria of Oculina patagonica. FEMS Microbiol Lett. 2009;292: 210-5.

7. Ritchie KB. Regulation of microbial populations by coral surface mucus and mucus-associated bacteria. Mar Ecol Prog Ser. 2006:322:1-14.

8. Ainsworth TD, Thurber RV, Gates RD. The future of coral reefs: a microbial perspective. Trends Ecol Evol. 2010;25:233-40.

9. Krediet CJ, Ritchie KB, Paul VJ, Teplitski M. Coral-associated micro-organisms and their roles in promoting coral health and thwarting diseases. Proc $\mathrm{R}$ Soc B Biol Sci. 2013;280. https://doi.org/10.1098/rspb.2012.2328.

10. Apprill A, Marlow HQ, Martindale MQ, Rappe MS. The onset of microbial associations in the coral Pocillopora meandrina. ISME J. 2009:3:685-99.

11. Sharp KH, Ritchie KB, Schupp PJ, Ritson-Williams R, Paul VJ. Bacterial acquisition in juveniles of several broadcast spawning coral species. PLoS One. 2010;5. https://doi.org/10.1371/journal.pone.0010898.

12. Ceh J, van Keulen M, Bourne DG. Coral-associated bacterial communities on Ningaloo Reef, Western Australia. FEMS Microbiol Ecol. 2011;75:134-44.

13. Sharp KH, Distel D, Paul VJ. Diversity and dynamics of bacterial communities in early life stages of the Caribbean coral Porites astreoides. ISME J. 2012. https://doi.org/10.1038/ismej.2011.144.

14. Apprill A, Weber LG, Santoro AE. Distinguishing between microbial habitats unravels ecological complexity in coral microbiomes. mSystems. 2016;1: e00143-16.

15. Bayer T, Neave MJ, Alsheikh-Hussain A, Aranda M, Yum LK, Mincer T, Hughen K, Apprill A, Voolstra CR. The microbiome of the Red Sea coral Stylophora pistillata is dominated by tissue-associated Endozoicomonas bacteria. Appl Environ Microbiol. 2013;79:4759-62.

16. Frias-Lopez J, Shi Y, Tyson GW, Coleman ML, Schuster SC, Chisholm SW, DeLong EF. Microbial community gene expression in ocean surface waters. Proc Natl Acad Sci. 2008;105:3805-10.

17. Roder C, Arif C, Daniels C, Weil E, Voolstra CR. Bacterial profiling of White Plague Disease across corals and oceans indicates a conserved and distinct disease microbiome. Mol Ecol. 2014;23:965-74.

18. Bourne $D$, lida $Y$, Uthicke $S$, Smith-Keune $C$. Changes in coral-associated microbial communities during a bleaching event. ISME J. 2007;2:350-63.

19. Bourne DG, Garren M, Work TM, Rosenberg E, Smith GW, Harvell CD. Microbial disease and the coral holobiont. Trends Microbiol. 2009;17:554-62.

20. Garren M, Azam F. New directions in coral reef microbial ecology. Environ Microbiol. 2011. https://doi.org/10.1111/j.1462-2920.2011.02597.x.

21. Sharp KH, Ritchie KB. Multi-partner interactions in corals in the face of climate change. Biol Bull. 2012;223:66-77.
22. Aeby GS, Kenyon JC, Maragos JE, Potts DC. First record of mass coral bleaching in the Northwestern Hawaiian Islands. Coral Reefs. 2003;22:256.

23. Alling A, Doherty OR, Logan HE, Feldman L, Dustan P. Catastrophic coral mortality in the remote central Pacific Ocean: Kiribati, Phoenix islands. Atoll Res Bull. 2007:551:1-9.

24. Obura D, Mangubhai S. Coral mortality associated with thermal fluctuations in the Phoenix Islands, 2002-2005. Coral Reefs. 2011;30:607-19.

25. Hughes TP, Kerry JT, Álvarez-Noriega M, Álvarez-Romero JG, Anderson KD, Baird AH, Babcock RC, Beger M, Bellwood DR, Berkelmans R, Bridge TC, Butler IR, Byrne M, Cantin NE, Comeau S, Connolly SR, Cumming GS, Dalton SJ, Diaz-Pulido G, Eakin CM, Figueira WF, Gilmour JP, Harrison HB, Heron SF, Hoey AS, Hobbs J-PA, Hoogenboom MO, Kennedy EV, Kuo C-Y, Lough JM, Lowe RJ, Liu G, McCulloch MT, Malcolm HA, McWilliam MJ, Pandolfi JM, Pears RJ, Pratchett MS, Schoepf V, Simpson T, Skirving WJ, Sommer B, Torda G, Wachenfeld DR, Willis BL, Wilson SK. Global warming and recurrent mass bleaching of corals. Nature. 2017;543:373-7.

26. Mouchka ME, Hewson I, Harvell CD. Coral-associated bacterial assemblages: current knowledge and the potential for climate-driven impacts. Integr Comp Biol. 2010;50:662-74.

27. Thurber RV, Willner-Hall D, Rodriguez-Mueller B, Desnues C, Edwards RA, Angly F, Dinsdale E, Kelly L, Rohwer F. Metagenomic analysis of stressed coral holobionts. Environ Microbiol. 2009;11:2148-63.

28. Meyer JL, Paul VJ, Teplitski M. Community shifts in the surface microbiomes of the coral Porites astreoides with unusual lesions. PLoS One. 2014;9: e100316.

29. Lajeunesse TC, Parkinson JE, Reimer JD. A genetics-based description of Symbiodinium minutum sp. nov. and S. psygmophilum sp. nov. (Dinophyceae), two dinoflagellates symbiotic with cnidaria. J Phycol. 2012; 48:1380-91.

30. Thornhill DJ, Kemp DW, Bruns BU, Fitt WK, Schmidt GW. Correspondence between cold tolerance and temperate biogeography in a western Atlantic Symbiodinium (Dinophyta) lineage. J Phycol. 2008;44:1126-35.

31. Szmant-Froelich A, Pilson MEQ. The effects of feeding frequency and symbiosis with zooxanthellae on nitrogen metabolism by the coral Astrangia danae. Mar Biol. 1984:81:153-62.

32. Dimond JD, Carrington E. Temporal variation in the symbiosis and growth of the temperate scleractinian coral Astrangia poculata. Mar Ecol Prog Ser. 2007;348:161-72.

33. Grace $\mathrm{S}$. Winter quiescence, growth rate and the release from competition in the temperate scleractinian coral Astrangia poculata (Ellis \& Solander 1786). Northeast Nat. In press

34. Grace $\mathrm{S}$. Winter quiescence, growth rate and the release from competition in the temperate scleractinian coral Astrangia poculata (Ellis \& Solander 1786). Northeastern Naturalist. 2017:24:B119-B134.

35. Burmester EM, Finnerty JR, Kaufman L, Rotjan RD. Temperature and symbiosis impact lesion recovery in experimentally wounded, facultatively symbiotic temperate corals. Mar Ecol Prog Ser. 2017; In press

36. DeFilippo L, Burmester EM, Kaufman L, Rotjan RD. Patterns of surface lesion recovery in the Northern Star Coral, Astrangia poculata. J Exp Mar Biol Ecol. 2016:481:15-24.

37. Kerwin $\mathrm{AH}$. The influence of Symbiodinium on the diversity of coralassociated bacteria and archaea in the temperate coral Astrangia poculata. MS Dissertation. Nahant, MA: Northeastern University, Marine Biology; 2010.

38. Johannes RE and Wiebe WJ. Method for determination of coral tissue biomass and composition. Limnology and Oceanography. 1970;15(5): 822-824.

39. Marsh JA. Primary productivity of reef-building calcareous red algae. Ecology. 1970;51:255-63.

40. Ganesh S, Parris DJ, DeLong EF, Stewart FJ. Metagenomic analysis of sizefractionated picoplankton in a marine oxygen minimum zone. ISME J. 2014; 8:187-211.

41. Caporaso JG, Lauber CL, Walters WA, Berg-Lyons D, Lozupone CA Turnbaugh PJ, Fierer N, Knight R. Global patterns of 165 rRNA diversity at a depth of millions of sequences per sample. Proc Natl Acad Sci. 2011:108: 4516-22.

42. Kozich JJ, Westcott SL, Baxter NT, Highlander SK, Schloss PD. Development of a dual-index sequencing strategy and curation pipeline for analyzing amplicon sequence data on the MiSeq Illumina sequencing platform. Appl Environ Microbiol. 2013;79:5112-20

43. Magoč T, Salzberg SL. FLASH: fast length adjustment of short reads to improve genome assemblies. Bioinformatics. 2011;27:2957-63. 
44. Caporaso JG, Kuczynski J, Stombaugh J, Bittinger K, Bushman FD, Costello EK, Fierer N, Pẽa AG, Goodrich JK, Gordon JI, Huttley GA, Kelley ST, Knights D, Koenig JE, Ley RE, Lozupone CA, McDonald D, Muegge BD, Pirrung M, Reeder J, Sevinsky JR, Turnbaugh PJ, Walters WA, Widmann J, Yatsunenko T, Zaneveld J, Knight R. QIIME allows analysis of high-throughput community sequencing data. Nat Methods. 2010;7:335-6.

45. DeSantis TZ, Hugenholtz P, Larsen N, Rojas M, Brodie EL, Keller K, Huber T, Dalevi D, Hu P, Andersen GL. Greengenes, a chimera-checked $16 S$ rRNA gene database and workbench compatible with ARB. Appl Environ Microbiol. 2006;72:5069-72.

46. Edgar RC. Search and clustering orders of magnitude faster than BLAST. Bioinformatics. 2010;26:2460-1.

47. Love Ml, Huber W, Anders S. Moderated estimation of fold change and dispersion for RNA-seq data with DESeq2. Genome Biol. 2014;15:550.

48. McMurdie PJ, Holmes S. Phyloseq: an R package for reproducible interactive analysis and graphics of microbiome census data. PLoS One. 2013;8. https:// doi.org/10.1371/journal.pone.0061217.

49. Oksanen J, Blanchet FG, Friendly M, Kindt R, Legendre P, McGlinn D, Minchin PR, O'Hara RB, Simpson GL, Solymos P, Stevens MHH, Szoecs E, Wagner H. Vegan: Community Ecology Package. R package version 2.3-4. 2016.

50. Bourne DG, Dennis PG, Uthicke S, Soo RM, Tyson GM, Webster N. Coral reef invertebrate microbiomes correlate with the presence of photosymbionts. ISME J. 2013;7:1459.

51. Raina JB, Dinsdale EA, Willis BL, Bourne DG. Do the organic sulfur compounds DMSP and DMS drive coral microbial associations? Trends Microbiol. 2010;18:101-8.

52. Cleary DFR, de Voogd NJ, Polónia ARM, Freitas R, Gomes NCM. Composition and predictive functional analysis of bacterial communities in seawater, sediment and sponges in the Spermonde Archipelago, Indonesia. Microb Ecol. 2015;70:889-903.

53. Schmidt EW, Obraztsova AY, Davidson SK, Faulkner DJ, Haygood MG. Identification of the antifungal peptide-containing symbiont of the marine sponge Theonella swinhoei as a novel $\delta$-proteobacterium, "Candidatus Entotheonella palauensis". Mar Biol. 2000;136:969-77.

54. Welsh RM, Rosales SM, Zaneveld JR, Payet JP, McMinds R, Hubbs SL, Thurber RLV. Alien vs. Predator: Pathogens open niche space for opportunists, unless controlled by predators. PeerJ. 2017;e3315. https://doi.org/10.7717/peerj. 3315 .

55. Neave MJ, Apprill A, Ferrier-Pagès C, Voolstra CR. Diversity and function of prevalent symbiotic marine bacteria in the genus Endozoicomonas. Appl Microbiol Biotechnol. 2016;100:8315-24.

56. Baumann P. Biology of bacteriocyte-associated endosymbionts of plant sapsucking insects. Annu Rev Microbiol. 2005;59:155-89.

57. Campbell AM, Fleisher J, Sinigalliano C, White JR, Lopez JV. Dynamics of marine bacterial community diversity of the coastal waters of the reefs, inlets, and wastewater outfalls of southeast Florida. MicrobiologyOpen. 2015;4:390-408.

58. Casas V, Kline D, Wegley L, Yu Y, Breitbart M, Rohwer F. Widespread association of a Rickettsiales-like bacterium with reef-building corals. Environ Microbiol. 2004;6:1137-48.

59. Kline DI, Vollmer SV. White Band Disease (type I) of endangered Caribbean Acroporid corals is caused by pathogenic bacteria. Sci Rep. 2011;1. https:// doi.org/10.1038/srep00007.

60. Röthig T, Costa RM, Simona F, Baumgarten S, Torres AF, Radhakrishnan A, Aranda M, Voolstra CR. Distinct bacterial communities associated with the coral model Aiptasia in aposymbiotic and symbiotic states with Symbiodinium. Front Mar Sci. 2016;3. https://doi.org/10.3389/fmars.2016. 00234.

61. Littman R, Willis BL, Bourne DG. Metagenomic analysis of the cora holobiont during a natural bleaching event on the Great Barrier Reef. Environ Microbiol Rep. 2011;3:651-60.

62. Littman RA, Willis BL, Bourne DG. Bacterial communities of juvenile corals infected with different Symbiodinium (dinoflagellate) clades. Mar Ecol Prog Ser. 2009;389:45-59.

63. Brown BE, Bythell JC. Perspectives on mucus secretion in reef corals. Mar Ecol Prog Ser. 2005;296:291-309.

64. Bythell JC, Wild CE. Biology and ecology of coral mucus release. J Exp Mar Biol Ecol. 2011;408:88-93.
65. Ishak HD, Miller JL, Sen R, Dowd SE, Meyer E, Mueller UG. Microbiomes of ant castes implicate new microbial roles in the fungus-growing ant Trachymyrmex septentrionalis. Sci Rep. 2011;1:204.

66. Wagner MR, Lundberg DS, Coleman-Derr D, Tringe SG, Dangl JL, MitchellOlds T. Natural soil microbes alter flowering phenology and the intensity of selection on flowering time in a wild Arabidopsis relative. Ecol Lett. 2014;17: 717-26.

67. Zaneveld JR, Burkepile DE, Shantz AA, Pritchard CE, McMinds R, Payet JP, Welsh R, Correa AMS, Lemoine NP, Rosales S, Fuchs C, Maynard JA, Thurber RV. Overfishing and nutrient pollution interact with temperature to disrupt coral reefs down to microbial scales. Nat Commun. 2016;7:11833.

68. Charlson ES, Chen J, Custers-Allen R, Bittinger K, Li H, Sinha R, Hwang J, Bushman FD, Collman RG. Disordered microbial communities in the upper respiratory tract of cigarette smokers. PLoS One. 2010;5:e15216.

69. Moeller AH, Li Y, Mpoudi Ngole E, Ahuka-Mundeke S, Lonsdorf EV, Pusey AE, Peeters M, Hahn BH, Ochman H. Rapid changes in the gut microbiome during human evolution. Proc Natl Acad Sci. 2014;111:16431-5.

70. Glasl B, Herndl GJ, Frade PR. The microbiome of coral surface mucus has a key role in mediating holobiont health and survival upon disturbance. ISME ।. 2016;10:2280-92.

71. Egan S, Gardiner M. Microbial dysbiosis: rethinking disease in marine ecosystems. Front Microbiol. 2016;7. https://doi.org/10.3389/fmicb.2016. 00991.

72. Sweet MJ, Bulling MT. On the importance of the microbiome and pathobiome in coral health and disease. Front Mar Sci. 2017;4. https://doi. org/10.3389/fmars.2017.00009.

73. Hernandez-Agreda A, Leggat W, Bongaerts P, Ainsworth TD. The microbial signature provides insight into the mechanistic basis of coral success across reef habitats. MBio. 2016;7. https://doi.org/10.1128/mBio.00560-16.

74. Feng G, Sun W, Zhang F, Karthik L, Li Z. Inhabitancy of active Nitrosopumilus-like ammonia-oxidizing archaea and Nitrospira nitriteoxidizing bacteria in the sponge Theonella swinhoei. Sci Rep. 2016;6:24966.

75. Gaidos E, Rusch A, llardo M. Ribosomal tag pyrosequencing of DNA and RNA from benthic coral reef microbiota: community spatial structure, rare members and nitrogen-cycling guilds. Environ Microbiol. 2011;13:1138-52.

76. Siboni N, Ben-Dov E, Sivan A, Kushmaro A. Global distribution and diversity of coral-associated Archaea and their possible role in the coral holobiont nitrogen cycle. Environ Microbiol. 2008;10:2979-90.

77. Ainsworth T, Krause L, Bridge T, Torda G, Raina J-B, Zakrzewski M, Gates RD, Padilla-Gamino JL, Spalding HL, Smith C, Woolsey ES, Bourne DG, Bongaerts P, Hoegh-Guldberg O, Leggat W. The coral core microbiome identifies rare bacterial taxa as ubiquitous endosymbionts. ISME J. 2015;9:2261-74.

78. Dimond JD, Kerwin A, Rotjan RD, Sharp KH, Stewart FJ, Thornhill DJ. A simple temperature-based model predicts the upper latitudinal limit of the temperate coral Astrangia poculata. Coral Reefs. 2013;32:401-9.

79. Lawler SN, Kellogg CA, France SC, Clostio RW, Brooke SD, Ross SW. Coralassociated bacterial diversity is conserved across two deep-sea Anthothela species. Front Microbiol. 2016;7. https://doi.org/10.3389/fmicb.2016.00458.

80. Hernández-Zulueta J, Araya R, Vargas-Ponce O, Díaz-Pérez L, RodríguezTroncoso AP, Ceh J, Ríos-Jara E, Rodríguez-Zaragoza FA. First deep screening of bacterial assemblages associated with corals of the Tropical Eastern Pacific. FEMS Microbiol Ecol. 2016;92. https://doi.org/10.1093/ femsec/fiw196.

81. Thackeray SJ, Sparks TH, Frederiksen M, Burthe S, Bacon PJ, Bell JR, Botham MS, Brereton TM, Bright PW, Carvalho L, Clutton-Brock TIM, Dawson A Edwards M, Elliott JM, Harrington R, Johns D, Jones ID, Jones JT, Leech DI, Roy DB, Scott WA, Smith M, Smithers RJ, Winfield IJ, Wanless S. Trophic level asynchrony in rates of phenological change for marine, freshwater and terrestrial environments. Glob Chang Biol. 2010;16:3304-13. 